\title{
PERBANDINGAN INTENSI KEWIRAUSAHAAN MAHASISWA \\ FAKULTAS EKONOMI UNIVERSITAS NEGERI MALANG: JURUSAN AKUNTANSI, MANAJEMEN DAN EKONOMI PEMBANGUNAN
}

\author{
Bety Nur Achadiyah \\ bety.achadiyah@um.ac.id \\ Diana Tien Irafami \\ Fakultas Ekonomi Universitas Negeri Malang
}

\begin{abstract}
ABSTRAK
Penelitian ini dilakukan untuk membandingkan intensi kewirausahaan mahasiswa Fakultas Ekonomi Universitas Negeri Malang pada tiga jurusan yaitu Akuntansi, Manajemen dan Ekonomi Pembangunan. Survei yang dilakukan terhadap 300 mahasiswa pada ketiga jurusan tersebut menunjukkan temuan bahwa intensi kewirausahaan diantara seluruh mahasiswa tidak dipengaruhi secara signifikan oleh pengalaman kerja. Sementara itu, efikasi diri mempengaruhi intensi kewirausahaan hanya pada mahasiswa jurusan Akuntansi. Disisi lain, hasil dari penelitian ini mengindikasikan bahwa kesiapan insrtrumen menjadi kunci utama yang mempengaruhi intensi kewirausahaan bagi mahasiswa jurusan Manajemen dan Ekonomi Pembangunan. Temuan dalam penelitian ini juga mengindikasikan bahwa kebutuhan akan prestasi tidak memiliki dampak signifikan. Lebih jauh lagi, hasil dari penelitian ini diharapkan mampu menjadi tilikan bagi universits dan pemerintah.
\end{abstract}

Kata Kunci: intensi kewirausaaan, kebutuhan akan prestasi, efikasi diri, kesiapan instrumen.

\section{ABSTRACT}

This study has been conducted to compare the entrepreneurial intentions among the students of Economics Faculty State University of Malang in the three different departments namely Accounting, Management and Economic Development. Survey towards 300 students from those three different departments reveal that entrepreneurial intentions among all students are not influenced significantly by working experience. Meanwhile, self efficacy influence entrepreneurial intention only among Accounting students. On the other hands, the results of this study indicate that instrumental readiness becomes key factor that influence entrepreneurial intention among the Management and the Economic Development students. The findings in this study also indicate that the need for achievement has no statistically significant impact. Moreover, this study is expected to be insight for universities and government institutions.

Keywords: entrepreneur intention, needs for achievement, self efficacy, instrumental readiness 


\section{JURNAL NOMINAL / VOLUME II NOMOR II / TAHUN 2013}

\section{A. PENDAHULUAN}

Kewirausahaan adalah salah satu matakuliah yang diberikan di semua jurusan di Fakultas Ekonomi (FE) Universitas Negeri Malang (UM). Pengaruh pendidikan kewirausahaan selama ini telah dipertimbangkan sebagai salah satu faktor penting untuk menumbuhkan dan mengembangkan hasrat, jiwa dan perilaku berwirausaha di kalangan generasi muda (Kourilsky dan Walstad, 1998). Terkait dengan pengaruh pendidikan kewirausahaan tersebut, diperlukan adanya pemahaman tentang bagaimana mengembangkan dan mendorong lahirnya wirausahawirausaha muda yang potensial sementara mereka berada di bangku sekolah. Beberapa penelitian sebelumnya menyebutkan bahwa keinginan berwirausaha para mahasiswa merupakan sumber bagi lahirnya wirausaha-wirausaha masa depan (Gorman et al., 1997; Kourilsky dan Walstad, 1998). Sikap, perilaku, dan pengetahuan mereka tentang kewirausahaan akan membentuk kecenderungan mereka untuk membuka usaha-usaha baru di masa mendatang.

Penelitian ini dimaksudkan untuk memberikan gambaran mengenai intensi kewirausahaan mahasiswa dan faktor-faktor pendorongnya. Survey dilakukan kepada mahasiswa di tiga program studi yang berbeda di Fakultas Ekonomi Universitas Negeri Malang, yaitu mahasiswa pada jurusan akuntansi, manajemen, dan ekonomi pembangunan. Hasil temuan ini diharapkan dapat menjadi masukan bagi pihak perguruan tinggi, pengambil kebijakan dan institusi terkait lainnya untuk mengembangkan program pendidikan yang tepat dalam mendorong semangat kewirausahaan.

Penelitian untuk melihat aspek intensi kewirausahaan seseorang telah mendapat perhatian cukup besar dari para peneliti. Intensi kewirausahaan dapat diartikan sebagai keinginan/proses pencarian informasi yang dapat digunakan untuk mencapai tujuan pembentukan suatu usaha (Katz dan Gartner, 1988). Seseorang dengan intensi untuk memulai usaha akan memiliki kesiapan dan kemajuan yang lebih baik dalam usaha yang dijalankan dibandingkan seseorang tanpa intensi untuk memulai usaha. Seperti yang dinyatakan oleh Krueger dan Carsrud (1993), intensi telah terbukti menjadi prediktor yang terbaik bagi perilaku kewirausahaan. Oleh karena itu, intensi dapat dijadikan sebagai pendekatan dasar 


\section{JURNAL NOMINAL / VOLUME II NOMOR II / TAHUN 2013}

yang masuk akal untuk memahami siapa-siapa yang akan menjadi wirausaha (Choo dan Wong, 2006).

Secara garis besar penelitian seputar intensi kewirausahaan dilakukan dengan melihat tiga hal secara berbeda-beda: karakteristik kepribadian; karakteristik demografis; dan karakteristik lingkungan. Beberapa peneliti terdahulu membuktikan bahwa faktor kepribadian seperti kebutuhan akan prestasi (McClelland, 1961; Sengupta dan Debnath, 1994) dan efikasi diri (Gilles dan Rea, 1999; Indarti, 2004) merupakan prediktor signifikan intensi kewirausahaan. Faktor demografi seperti umur, jenis kelamin, latar belakang pendidikan dan pengalaman bekerja seseorang diperhitungkan sebagai penentu bagi intensi kewirausahaan. Sebagai contoh, penelitian dari India (Sinha, 1996) menemukan bahwa latar belakang pendidikan seseorang menentukan tingkat intensi seseorang dan kesuksesan suatu bisnis yang dijalankan. Kristiansen (2001; 2002a) menyebut bahwa faktor lingkungan seperti hubungan sosial, infrastruktur fisik dan institusional serta faktor budaya dapat mempengaruhi intensi kewirausahaan.

McClelland (1961, 1971) telah memperkenalkan konsep kebutuhan akan prestasi sebagai salah satu motif psikologis. Kebutuhan akan prestasi dapat diartikan sebagai suatu kesatuan watak yang memotivasi seseorang untuk menghadapi tantangan untuk mencapai kesuksesan dan keunggulan (Lee, 1997: 103). Lebih lanjut, McClelland (1976) menegaskan bahwa kebutuhan akan prestasi sebagai salah satu karakteristik kepribadian seseorang yang akan mendorong seseorang untuk memiliki intensi kewirausahaan. Menurutnya, ada tiga atribut yang melekat pada seseorang yang mempunyai kebutuhan akan prestasi yang tinggi, yaitu: (a) menyukai tanggung jawab pribadi dalam mengambil keputusan, (b) mau mengambil risiko sesuai dengan kemampuannya, dan (c) memiliki minat untuk selalu belajar dari keputusan yang telah diambil.

Hasil penelitian dari Scapinello (1989) menunjukkan bahwa seseorang dengan tingkat kebutuhan akan prestasi yang tinggi kurang dapat menerima kegagalan daripada mereka dengan kebutuhan akan prestasi rendah. Dengan kata lain, kebutuhan akan prestasi berpengaruh pada atribut kesuksesan dan kegagalan. Sejalan dengan hal tersebut, Sengupta dan Debnath (1994) dalam penelitiannya di 


\section{JURNAL NOMINAL / VOLUME II NOMOR II / TAHUN 2013}

India menemukan bahwa kebutuhan akan prestasi berpengaruh besar dalam tingkat kesuksesan seorang wirausaha.

Lebih spesifik, kebutuhan akan prestasi juga dapat mendorong kemampuan pengambilan keputusan dan kecenderungan untuk mengambil risiko seorang wirausaha. Semakin tinggi kebutuhan akan prestasi seorang wirausaha, semakin banyak keputusan tepat yang akan diambil. Wirausaha dengan kebutuhan akan prestasi tinggi adalah pengambil resiko yang moderat dan menyukai hal-hal yang menyediakan balikan yang tepat dan cepat.

\section{Hipotesis 1: Kebutuhan akan prestasi mempengaruhi intensi kewirausahaan}

Bandura (1977: 2) mendefinisikan efikasi diri sebagai kepercayaan seseorang atas kemampuan dirinya untuk menyelesaikan suatu pekerjaan. Atau dengan kata lain, kondisi motivasi seseorang yang lebih didasarkan pada apa yang mereka percaya daripada apa yang secara objektif benar. Persepsi pribadi seperti ini memegang peranan penting dalam pengembangan intensi seseorang. Senada dengan hal tersebut, Cromie (2000) menjelaskan bahwa efikasi diri mempengaruhi kepercayaan seseorang pada tercapai atau tidaknya tujuan yang sudah ditetapkan.

Lebih rinci, Bandura (1986) menjelaskan empat cara untuk mencapai efikasi diri. Pertama, pengalaman sukses yang terjadi berulang-ulang. Cara ini dipandang sebagai cara yang sangat efektif untuk mengembangkan rasa yang kuat pada efikasi diri. Kedua, pembelajaran melalui pengamatan secara langsung. Dengan cara ini, seseorang akan memperkirakan keahlian dan perilaku yang relevan untuk dijadikan contoh dalam mengerjakan sebuah tugas. Penilaian atas keahlian yang dimilikinya juga dilakukan, untuk mengetahui besar usaha yang harus dikeluarkan dalam rangka mencapai keahlian yang dibutuhkan. Ketiga, persuasi sosial seperti diskusi yang persuasif dan balikan kinerja yang spesifik. Dengan metode ini, memungkinkan untuk menyajikan informasi terkait dengan kemampuan seseorang dalam menyelesaikan suatu pekerjaan. Keempat, penilaian terhadap status psikologis yang dimiliki. Hal ini berarti bahwa seseorang sudah seharusnya meningkatkan kemampuan emosional dan fisik serta mengurangi tingkat stres.

Di sisi lain, banyak peneliti percaya bahwa efikasi diri terkait erat dengan pengembangan karier. Merujuk Betz dan Hacket (1986), efikasi diri akan karier 


\section{JURNAL NOMINAL / VOLUME II NOMOR II / TAHUN 2013}

seseorang adalah domain yang menggambarkan pendapat pribadi seseorang dalam hubungannya dengan proses pemilihan dan penyesuaian karier. Dengan demikian, efikasi diri akan karier seseorang dapat menjadi faktor penting dalam penentuan apakah intense kewirausahaan seseorang sudah terbentuk pada tahapan awal seseorang memulai kariernya. Lebih lanjut, Betz dan Hacket menyatakan bahwa semakin tinggi tingkat efikasi diri seseorang pada kewirausahaan di masa-masa awal seseorang dalam berkarier, semakin kuat intensi kewirausahaan yang dimilikinya. Selain itu, Gilles dan Rea (1999) membuktikan pentingnya efikasi diri dalam proses pengambilan keputusan terkait dengan karier seseorang. Efikasi diri terbukti signifikan menjadi penentu intensi seseorang.

Berdasarkan uraian tersebut, hipotesis kedua yang akan dijawab dalam penelitian ini adalah sebagai berikut.

\section{Hipotesis 2: Efikasi diri berpengaruh terhadap intensi kewirausahaan}

Tiga faktor lingkungan yang dipercaya mempengaruhi wirausaha yaitu aksesmereka kepada modal, informasi, dan kualitas jaringan sosial yang dimiliki, yang kemudian disebut kesiapan instrumen (Indarti, 2004). Akses kepada modal merupakan hambatan klasik terutama dalam memulai usaha-usaha baru, setidaknya terjadi di negara-negara berkembang dengan dukungan lembagalembaga penyedia keuangan yang tidak begitu kuat (Indarti, 2004). Studi empiris terdahulu menyebutkan bahwa kesulitan dalam mendapatkan akses modal, skema kredit, dan kendala sistem keuangan dipandang sebagai hambatan utama dalam kesuksesan usaha menurut calon-calon wirausaha di negara-negara berkembang (Marsden, 1992; Meier dan Pilgrim, 1994; Steel, 1994).

Di negara-negara maju di mana infrastruktur keuangan sangat efisien, akses kepada modal juga dipersepsikan sebagai hambatan untuk menjadi pilihan wirausaha karena tingginya hambatan masuk untuk mendapatkan modal yang besar terhadap rasio tenaga kerja di banyak industri yang ada. Penelitian relatif baru menyebutkan bahwa akses kepada modal menjadi salah satu penentu kesuksesan suatu usaha (Kristiansen et al., 2003; Indarti, 2004).

Ketersediaan informasi usaha merupakan faktor penting yang mendorong keinginan seseorang untuk membuka usaha baru (Indarti, 2004) dan faktor kritikal bagi pertumbuhan dan keberlangsungan usaha (Duh, 2003; Kristiansen, 2002b; 


\section{JURNAL NOMINAL / VOLUME II NOMOR II / TAHUN 2013}

Mead \& Liedholm, 1998; Swierczek dan Ha, 2003). Penelitian yang dilakukan oleh Singh dan Krishna (1994) di India membuktikan bahwa keinginan yang kuat untuk memperoleh informasi adalah salah satu karakter utama seorang wirausaha. Pencarian informasi mengacu pada frekuensi kontak yang dibuat oleh seseorang dengan berbagai sumber informasi. Hasil dari aktivitas tersebut sering tergantung pada ketersediaan informasi, baik melalui usaha sendiri atau sebagai bagian dari sumber daya sosial dan jaringan. Ketersediaan informasi baru akan tergantung pada karakteristik seseorang, seperti tingkat pendidikan dan kualitas infrastruktur, meliputi cakupan media dan sistem telekomunikasi (Kristiansen, 2002b).

Mazzarol et al. (1999) menyebutkan bahwa jaringan sosial mempengaruhi intense kewirausahaan. Jaringan sosial didefinisikan sebagai hubungan antara dua orang yang mencakup a) komunikasi atau penyampaian informasi dari satu pihak ke pihak lain; b) pertukaran barang dan jasa dari dua belah pihak; dan c) muatan normatif atau ekspektasi yang dimiliki oleh seseorang terhadap orang lain karena karakter-karakter atau atribut khusus yang ada. Bagi wirausaha, jaringan merupakan alat mengurangi risiko dan biaya transaksi serta memperbaiki akses terhadap ide-ide bisnis, informasi, dan modal (Aldrich dan Zimmer, 1986). Hal senada diungkap oleh Kristiansen (2003) yang menjelaskan bahwa jaringan sosial terdiri dari hubungan formal dan informal antara pelaku utama dan pendukung dalam satu lingkaran terkait dan menggambarkan jalur bagi wirausaha untuk mendapatkan akses kepada sumber daya yang diperlukan dalam pendirian, perkembangan, dan kesuksesan usaha. Dari penjelasan tersebut, maka hipotesis yang akan diuji dalam penelitian ini adalah:

\section{Hipotesis 3: Kesiapan instrumen berpengaruh terhadap intensi kewirausahaan}

Kolvereid (1996) menemukan bahwa seseorang yang memiliki pengalaman bekerja mempunyai intensi kewirausahaan yang lebih tinggi dibandingkan mereka yang tidak pernah bekerja sebelumnya. Sebaliknya, secara lebih spesifik, penelitian yang dilakukan oleh Mazzarol et al., (1999) membuktikan bahwa seseorang yang pernah bekerja di sektor pemerintahan cenderung kurang sukses untuk memulai usaha. Namun, Mazzarol et al., (1999) tidak menganalisis hubungan antara pengalaman kerja di sector swasta terhadap intensi kewirausahaan. Scott dan Twomey (1988) meneliti beberapa faktor seperti 
pengaruh orang tua dan pengalaman kerja yang akan mempengaruhi persepsi seseorang terhadap suatu usaha dan sikap orang tersebut terhadap keinginannya untuk menjadi karyawan atau wirausaha. Lebih lanjut, mereka menyebutkan bahwa jika kondisi lingkungan sosial seseorang pada saat dia berusia muda kondusif untuk kewirausahaan dan seseorang tersebut memiliki pengalaman yang positif terhadap sebuah usaha, maka dapat dipastikan orang tersebut mempunyai gambaran yang baik tentang kewirausahaan. Dengan demikian, maka dapat dikemukakan hipotesis sebagai berikut:

Hipotesis 4: Mahasiswa yang memiliki pengalaman kerja memiliki intensi kewirausahaan yang lebih tinggi dibandingkan dengan mereka yang belum pernah bekerja sebelumnya.

\section{B. METODE}

Jenis penelitian ini adalah penelitian eksplanasi yaitu penelitian yang dilakukan untuk menguji hubungan variabel yang dihipotesiskan yaitu variabel bebas dan variabel terikat. Penelitian ini diharapkan dapat memberikan penjelasan atas pengaruh faktor-faktor yang berkontribusi (variabel bebas) terhadap intensi kewirausahaan mahasiswa (variabel terikat). Adapun faktor-faktor yang digunakan sebagai prediktor intensi kewirausahaan adalah faktor kebutuhan akan prestasi, efikasi diri, kesiapan instrumen, dan pengalaman kerja.

Pengaruh antara variabel tersebut dapat digambarkan secara sistematis sebagai berikut:

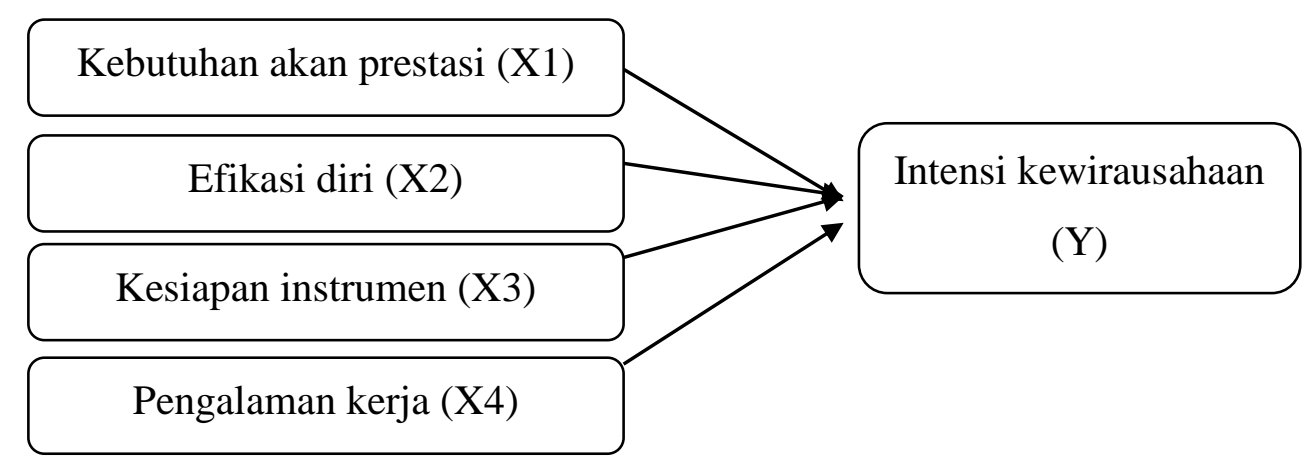

Gambar 1. Rancangan penelitian

1. Intensi kewirausahaan: niat atau keinginan seseorang untuk memulai membuka usaha/berwirausaha. 


\section{JURNAL NOMINAL / VOLUME II NOMOR II / TAHUN 2013}

2. Kebutuhan akan prestasi: suatu kesatuan watak (memiliki tanggung jawab pribadi, mau mengambil resiko, memiliki minat untuk selalu belajar) yang dapat memotivasi seseorang untuk menghadapi tantangan untuk mencapai kesuksesan.

3. Efikasi diri: kepercayaan seseorang atas kemampuan dirinya untuk menyelesaikan suatu pekerjaan.

4. Kesiapan instrumen: tiga atribut lingkungan yang dimiliki seseorang (akses kepada modal, informasi, dan jaringan sosial) yang dapat mempengaruhi keputusan untuk berwirausaha

5. Pengalaman kerja: latar belakang pekerjaan yang pernah atau sedang dilakukan seseorang.

6. Jurusan: kelompok konsentrasi pilihan studi mahasiswa di Fakultas Ekonomi Universitas Negeri Malang, yang terdiri dari jurusan akuntansi, jurusan manajemen, dan jurusan ekonomi pembangunan

Populasi penelitian ini adalah seluruh mahasiswa mahasiswa sarjana (S1) dan mahasiswa Diploma (D3) Fakultas Ekonomi Universitas Negeri Malang dari Jurusan Akuntansi, Manajemen dan Ekonomi Pembangunan. Pengambilan sampel dilakukan secara proporsional sesuai dengan jumlah mahasiswa pada masingmasing jurusan tersebut. Dengan demikian, jurusan yang memiliki jumlah mahasiswa lebih banyak dari jurusan lain akan mendapatkan kesempatan untuk menjadi responden yang lebih besar pula daripada jurusan lain.

Pengumpulan data dalam penelitian ini menggunakan teknik angket/kuesioner. Angket/kuesioner adalah daftar pertanyaan pengganti dari wawancara. Dengan menggunakan angket peneliti akan mendapatkan data yang lengkap tentang pengaruh faktor-faktor prediktor intensi kewirausahaan terhadap intensi kewirausahaan mahasiswa yang dijadikan subjek penelitian. Jenis angket ada 2 macam yaitu angket terbuka dan angket tertutup. Penelitian ini menggunakan angket tertutup, yaitu angket yang sudah menyediakan jawaban pertanyaan sehingga responden tinggal memilih saja (Arikunto, 2002:128).

Instrumen penelitian terdiri dari empat variabel independen penelitian dan satu variabel dependen yang dioperasionalisasikan menjadi beberapa butir pertanyaan. Satu variabel dependen yang dimaksud digunakan untuk mengukur 
intensi kewirausahaan. Seluruh butir pertanyaan diukur dengan menggunakan skala Likert 7-poin. Informasi tentang pengalaman kerja responden juga dikumpulkan dan dianggap sebagai variabel dummy dengan kode 0 dan 1 .

Kuesioner penelitian didistribusikan secara langsung dengan tujuan untuk mendapatkan tingkat pengembalian yang tinggi. Pengumpulan data dilakukan di sekitar kampus, terutama di area publik seperti kantin, perpustakaan, dan laboratorium komputer. Pengumpulan data dilakukan pada periode 2012, dengan sampel keseluruhan adalah 300 mahasiswa FE UM yang telah menempuh matakuliah kewirausahaan.

Bagian utama kuesioner terdiri dari butir-butir pertanyaan (multi-item scale) terkait dengan variabel utama penelitian. Beberapa butir pertanyaan digunakan untuk mengukur pertanyaan-pertanyaan sikap sehingga dapat lebih menjamin asumsi pengukuran level interval dibandingkan jika hanya satu item pertanyaan yang diajukan (Remenyi, 2000). Indeks masing-masing variabel dependen dan independen ditentukan dari rata-rata jawaban responden untuk setiap konstruk variabel.

Analisis data dalam penelitian ini dilakukan dengan teknik analisis regresi berganda. Teknik analisis ini digunakan untuk mengetahui sejauh mana pengaruh faktor-faktor prediktor intensi kewirausahaan terhadap intensi kewirausahaan. Persamaan yang menyatakan bentuk hubungan antara variabel bebas (X) dengan variabel terikat (Y) disebut persamaan regresi. Adapun model persamaan regresi dalam penelitian ini adalah sebagai berikut

$$
Y^{\prime}=a+b 1 \times 1+b 2 \times 2+b 3 \times 3+b 4 \times 4
$$

Pengujian prasyarat berupa uji normalitas, heterokedastisitas, dan multikolinearitas dilakukan terlebih dahulu sebelum analisis regresi berganda.

\section{HASIL DAN PEMBAHASAN}

\section{Hasil}

Kuesioner yang tersebar dan dapat diolah adalah sebanyak 300 kuesioner. Sebagian besar responden $(67,3 \%)$ berjenis kelamin perempuan. Responden yang berusia di bawah 20 tahun adalah sebesar 39,4\%, sementara 
responden yang berusia 20 tahun keatas adalah sebesar 60,6\%. Mayoritas responden $(91,0 \%)$ memiliki latar belakang pendidikan di bidang ekonomi dan bisnis.

Jika dilihat dari program yang diambil, 78,3\% responden adalah mahasiswa yang mengambil program strata $1 / \mathrm{S} 1$, sementara sisanya yaitu sebesar 21,7\% mengambil program diploma 3/D3. Sementara jika dilihat dari semester yang sedang ditempuh saat responden mengisi kuesioner penelitian, dapat diketahui bahwa sebagian besar responden $(58,3 \%)$ adalah mahasiswa semester 5-6. Mahasiswa yang sedang menempuh semester 1-2 adalah sebesar $16,0 \%$, semester $3-4$ adalah sebesar $25,3 \%$, sedangkan yang sedang menempuh semester 7-8 adalah sebesar $10,6 \%$. tidak ada responden yang menempuh kuliah di atas semester 8. Jika dilihat dari jurusan yang diambil responden, responden dari jurusan akuntansi adalah sebesar 30,7\%, dari jurusan manajemen adalah sebesar 43,0\%, dan dari jurusan ekonomi pembangunan adalah sebesar 26,3\%. Komposisi responden berdasarkan jurusan ini telah sesuai dengan proporsi populasi, dimana jurusan manajemen memiliki jumlah mahasiswa terbanyak, sehingga mendapatkan porsi pembagian angket yang paling banyak juga. Jumlah populasi terbanyak kedua adalah mahasiswa dari jurusan akuntansi dan yang paling sedikit adalah mahasiswa dari jurusan ekonomi pembangunan.

Sebelum dilakukan analisis data dengan regresi berganda, digunakan uji asumsi klasik untuk memastikan bahwa data layak untuk dianalisis dengan analisis regresi. Uji asumsi klasik yang dilakukan adalah uji normalitas, heterokedastisitas dan uji asumsi klasik.

Adapun hasil analisis regresi berganda pada tiga jurusan yaitu jurusan akuntansi, jurusan manajemen dan jurusan ekonomi pembangunan adalah sebagai berikut: 
Tabel 1 Ringkasan hasil analisis regresi berganda

\begin{tabular}{|l|c|c|c|}
\hline \multirow{2}{*}{\multicolumn{1}{|c|}{ Variabel }} & \multicolumn{3}{c|}{ B / sig. } \\
\cline { 2 - 4 } & Akuntansi & Manajemen & Ekonomi \\
\hline Kebutuhan Akan Prestasi & $0,090 / 0,179$ & $0,008 / 0,875$ & $0,106 / 0,068$ \\
\hline Efikasi Diri & $0,189 / 0,019$ & $-0,016 / 0,825$ & $-0,048 / 0,595$ \\
\hline Kesiapan Instrumen & $0,037 / 0,618$ & $0,308 / 0,000$ & $0,366 / 0,000$ \\
\hline Pengalaman Kerja & $0,265 / 0,301$ & $0,002 / 0,991$ & $-0,233 / 0,481$ \\
\hline $\mathrm{R}^{2}$ & 0,124 & 0,107 & 0,229 \\
\hline Adjusted R2 & 0,084 & 0,079 & 0,187 \\
\hline $\mathrm{F}$ & $3,091 / 0,020$ & $3,731 / 0,007$ & $5,481 / 0,001$ \\
\hline
\end{tabular}

\section{Pembahasan}

\section{Hipotesis 1}

Hipotesis pertama menyatakan bahwa "kebutuhan akan prestasi berpengaruh terhadap intensi kewirausahaan mahasiswa". Hasil pengujian hipotesis pada tiap jurusan tidak dapat membuktikan bahwa kebutuhan akan prestasi berpengaruh terhadap intensi kewirausahaan mahasiswa. Hal ini dapat dicermati pada tabel 1 di atas. Secara umum dapat dikatakan bahwa memang makin tinggi kebutuhan akan prestasi, makin tinggi pula intensi kewirausahaan mahasiswa sebagaimana terlihat pada koefisien regresi yang menunjukkan nilai positif pada semua jurusan. Namun, hasil ini tidak signifikan secara statistik, ditandai dengan nilai signifikansi hasil penelitian yang lebih besar dari alpha $(0,05)$.

Temuan ini tidak mendukung hasil penelitian-penelitian sebelumnya, misalnya penelitian McClelland (1961, 1971), penelitian Scapinello (1989), serta penelitian Sengupta dan Debnath (1994). Ketiga penelitian terdahulu ini menyatakan bahwa kebutuhan akan prestasi sebagai salah satu karakteristik kepribadian seseorang yang akan mendorong seseorang untuk memiliki intensi kewirausahaan. Seseorang dengan tiga atribut berikut yaitu: (a) menyukai tanggung jawab pribadi dalam mengambil keputusan, (b) mau mengambil risiko sesuai dengan kemampuannya, dan (c) memiliki minat untuk selalu belajar dari keputusan yang telah diambil, akan memiliki intensi kewirausahaan yang 
tinggi serta berpengaruh besar dalam tingkat kesuksesan seorang wirausaha.

Hasil penelitian ini senada dengan penelitian Indarti dan Rostiani (2008) yang menunjukkan bahwa tidak terdapat cukup bukti kebutuhan akan prestasi berpengaruh terhadap intensi kewirausahaan. Ketiga indikator kebutuhan akan prestasi sebagaimana yang didengungkan oleh McClelland (1961, 1971) lebih banyak digunakan masyarakat Indonesia dalam konteks bekerja di perusahaan, bukan sebagai enterpreneur. Hal ini kemungkinan menjadi faktor penjelas mengapa kebutuhan akan prestasi tidak berpengaruh terhadap intensi kewirausahaan.

\section{Hipotesis 2}

Hipotesis kedua menyatakan bahwa "efikasi diri berpengaruh terhadap intensi kewirausahaan mahasiswa". Dari tabel 1 dapat dilihat bahwa hipotesis kedua ini hanya diterima pada hasil penelitian pada responden di jurusan akuntansi dengan nilai signifikasi 0,019 yang dibawah alpha $(0,05)$. Sedangkan pada responden di jurusan manajemen dan ekonomi pembangunan, tidak terdapat cukup bukti untuk menerima hipotesis kedua. Ini ditandai dengan nilai signifikansi hasil penelitian yang lebih besar dari alpha $(0,05)$ yaitu masing-masing sebesar 0,825 dan 0,595 .

Hasil penelitian ini menunjukkan bahwa bagi mahasiswa jurusan akuntansi, efikasi diri merupakan faktor yang menentukan intensi berwirausaha. Semakin tinggi tingkat kepercayaan diri seorang mahasiswa atas kemampuan dirinya untuk dapat berusaha, maka semakin besar pula keinginannya untuk menjadi seorang wirausahawan. Hal ini sejalan dengan penelitian sebelumnya misalnya Bandura (1986), Betz dan Hacket (1986), Cromie (2000), serta penelitian Indarti dan Rostiani (2008).

Akan tetapi, penelitian ini menemukan bahwa efikasi diri tidak berpengaruh signifikan dalam konteks mahasiswa jurusan manajemen dan jurusan ekonomi pembangunan. Seseorang yang yakin akan 


\section{JURNAL NOMINAL / VOLUME II NOMOR II / TAHUN 2013}

kemampuan dirinya tidak serta merta memiliki keinginan untuk berwirausaha.

\section{Hipotesis 3}

Hipotesis ketiga menyatakan bahwa "kesiapan instrumen berpengaruh terhadap intensi kewirausahaan mahasiswa". Analisis regresi sebagaimana terlihat pada tabel 1 menunjukkan bahwa kesiapan instrumen merupakan prediktor yang signifikan bagi intensi kewirausahaan mahasiswa jurusan manajemen dan ekonomi pembangunan. Kesiapan instrumen yang baik mencakup ketersediaan modal, jaringan sosial dan kemudahan akses pada informasi. Ketiga indikator ini akan mendukung semangat untuk berwirausaha. Hasil ini merupakan kebalikan dari hasil analisis pada variabel sebelumnya yaitu variabel efikasi diri. Pada variabel efikasi diri, tidak ada ada pengaruh efikasi diri terhadap intensi kewirausahaan mahasiswa manajemen dan ekonomi pembangunan. Sementara variabel kesiapan instrumen justru terbukti berpengaruh signifikan pada keinginan berwirausaha mahasiswa jurusan manajemen dan ekonomi pembangunan.

Temuan ini memperkuat hasil penelitian sebelumnya, antara lain Sabbarwal (1994), Kristiansen (2001), Mazzarol et al. (1999), serta penelitian Indarti dan Rostiani (2008). Sementara, kesiapan instrumen tidak signifikan mempengaruh intensi kewirausahaan mahasiswa jurusan akuntansi. Dengan demikian dapat dipahami bahwa bagi mahasiswa jurusan akuntansi, faktor ketersediaan modal, jaringan sosial dan kemudahan akses pada informasi bukanlah faktor penentu besar kecilnya keinginan untuk berwirausaha. Justru efikasi diri yang merupakan rasa kepercayaan akan kemampuannya untuk berwirausaha lebih dominan dalam menjelaskan variabel intensi kewirausahaan.

Sebaliknya, bagi mahasiswa jurusan manajemen dan ekonomi pembangunan, efikasi diri tidak cukup untuk membangkitkan semangat berwirausaha. Mereka cenderung berfikir logis dan realistis sehingga bagi mahasiswa jurusan manajemen dan ekonomi pembangunan, kesiapan instrumen yang meliputi akses terhadap modal, koneksi dan 
informasi dianggap sebagai faktor penentu ingin tidaknya mereka berwirausaha.

\section{Hipotesis 4}

Hipotesis keempat menyatakan bahwa "pengalaman kerja berpengaruh terhadap intensi kewirausahaan mahasiswa". Hasil penelitian ini tidak mendukung hipotesis keempat. Hal ini ditandai dengan nilai signifikansi pada tabel 4.2 yang lebih besar dari alpha $(0,05)$ yaitu masing-masing sebesar 0,301 bagi mahasiswa jurusan akuntansi, 0,991 bagi mahasiswa jurusan manajemen dan 0,481 bagi mahasiswa jurusan ekonomi pembangunan. Hasil penelitian ini bertolak belakang dengan hasil penelitian Scott dan Twomey (1988), Kolvereid (1996) serta penelitian Indarti dan Rostiani (2008). Dengan demikian ada tidaknya pengalaman kerja tidak berpengaruh terhadap keinginan mahasiswa untuk berwirausaha. Bahkan koefisien pengalaman kerja pada jurusan ekonomi pembangunan menunjukkan nilai negatif, yang walaupun tidak signifikan secara statistik, menggambarkan kecenderungan bahwa makin banyak pengalaman kerja, justru makin sedikit keinginan untuk berwirausaha. Hal ini mengindikasikan betapa seseorang enggan keluar dari "zona aman". Seseorang yang telah bekerja dalam arti menjadi pegawai/karyawan baik di sektor swasta ataupun pemerintahan cenderung tidak ingin beralih untuk menjadi wirausaha.

Jika dilakukan analisis secara bersamaan dimana data tidak dipisahkan menurut jurusan, maka hasil analisis regresi berganda akan dapat dilihat pada tabel 2 berikut. 
Tabel 2: Hasil analisis regresi berganda

Coefficients $^{\mathrm{a}}$

\begin{tabular}{|c|c|c|c|c|c|c|}
\hline \multirow{2}{*}{\multicolumn{2}{|c|}{ Model }} & \multicolumn{2}{|c|}{$\begin{array}{c}\text { Unstandardized } \\
\text { Coefficients }\end{array}$} & \multirow{2}{*}{\begin{tabular}{|c|}
$\begin{array}{c}\text { Standardized } \\
\text { Coefficients }\end{array}$ \\
Beta \\
\end{tabular}} & \multirow[b]{2}{*}{$\mathrm{t}$} & \multirow[b]{2}{*}{ Sig. } \\
\hline & & $\mathrm{B}$ & Std. Error & & & \\
\hline \multirow[t]{5}{*}{1} & (Constant) & 8.698 & 1.340 & & 6.490 & .000 \\
\hline & kebutuhanPrestasi & .057 & .032 & .101 & 1.763 & .079 \\
\hline & efikasiDiri & .031 & .047 & .038 & .664 & .507 \\
\hline & kesiapanInstrumen & .236 & .048 & .280 & 4.914 & .000 \\
\hline & pengalamankerja & -.032 & .141 & -.012 & -.225 & .822 \\
\hline
\end{tabular}

a. Dependent Variable: IntensiKewirausahaan

Berdasarkan tabel 2 yang merupakan analisis gabungan dari tiga jurusan dapat diketahui bahwa hanya variabel kesiapan instrumen yang signifikan berpengaruh terhadap intensi kewirausahaan. Ini menunjukkan mahasiswa cenderung berfikir realistis untuk berwirausaha. Kesiapan modal, jaringan sosial yang kuat dan akses terhadap informasi lebih berperan dalam menentukan keinginan berwirausaha.

Jika dibandingkan intensi kewirausahaan mahasiswa jurusan akuntansi, jurusan manajemen dan jurusan ekonomi pembangunan, terlihat tidak ada perbedaan yang signifikan antara mahasiswa di ketiga jurusan tersebut terkait dengan keinginan untuk berwirausaha. Hal ini terlihat pada tabel 3 berikut:

Tabel 3 Uji beda intensi kewirausahaan 3 jurusan

\section{ANOVA}

intensiKewirausahaan

\begin{tabular}{|l|r|r|r|r|r|}
\hline & \multicolumn{1}{|c|}{$\begin{array}{c}\text { Sum of } \\
\text { Squares }\end{array}$} & Df & Mean Square & F & \multicolumn{1}{c|}{ Sig. } \\
\hline Between & 2.642 & 2 & 1.321 & .268 & .765 \\
Groups & 1461.278 & 297 & 4.920 & & \\
Within Groups & 1463.920 & 299 & & & \\
Total & & & \\
\hline
\end{tabular}

Meskipun matakuliah kewirausahaan diberikan pada semua jurusan di Fakultas Ekonomi Universitas Negeri Malang baik di jurusan 
Akuntansi, jurusan Manajemen dan jurusan Ekonomi Pembangunan, namun "virus kewirausahaan" lebih banyak diberikan pada mahasiswa jurusan manajemen. Hal ini dikarenakan struktur kurikulum pada jurusan manajemen khususnya manajemen pemasaran memungkinkan aspek kewirausahaan masuk pada hampir seluruh konten matakuliah, tidak hanya pada matakuliah kewirausahaan semata.

Perbedaan intensitas pemberian pengetahuan kewirausahaan pada mahasiswa di 3 jurusan ini ternyata tidak secara signifikan menyebabkan perbedaan cara pandang mahasiswa dalam memahami kewirausahaan dan sekaligus tidak menyebabkan perbedaan intensi kewirausahaan mereka. Mahasiswa dari ketiga jurusan terlihat tidak terlalu menunjukkan keinginan untuk berwirausaha yang ditandai dengan rerata intensi kewirausahaan mahasiswa sebesar 4,6 yang masuk kategori netral atau tidak yakin akan keinginannya untuk berwirausaha.

\section{PENUTUP}

Kesimpulan dari hasil penelitian ini adalah sebagai berikut:

1. Kebutuhan akan prestasi tidak berpengaruh terhadap intensi kewirausahaan mahasiswa akuntansi, manajemen dan ekonomi pembangunan.

2. Efikasi diri berpengaruh terhadap intensi kewirausahaan mahasiswa akuntansi, sementara pada mahasiswa manajemen dan ekonomi pembangunan efikasi diri tidak berpengaruh terhadap intensi kewirausahaan mahasiswa.

3. Kesiapan instrumen berpengaruh terhadap intensi kewirausahaan mahasiswa manajemen dan ekonomi pembangunan, sementara pada mahasiswa akuntansi, kesiapan instrumen tidak berpengaruh terhadap intensi kewirausahaan.

4. Pengalaman kerja tidak berpengaruh terhadap intensi kewirausahaan mahasiswa akuntansi, manajemen dan ekonomi pembangunan.

5. Jika data pada ketiga jurusan digabungkan, hanya variabel kesiapan instrumen yang berpengaruh signifikan terhadap intensi kewirausahaan mahasiswa. 


\section{E. DAFTAR PUSTAKA}

Aldrich, H., dan C. Zimmer, 1986. "Entrepreneurship through Social Network", in D. L. Sexton and R. W. Smilor (eds.) The Art and Science of Entrepreneurship,Cambridge: Ballinger Publishing, 3-25.

Bandura, A., 1977. Social Learning Theory, Englewood Cliffs, New Jersey: Prentice Hall.

Bandura, A., 1986. The Social Foundation of Tought and Action, Englewood Cliffs, NJ: Prentice-Hall.

Choo, S., dan M. Wong, 2006. "Entrepreneurial intention: triggers and barriers to new venture creations in Singapore". Singapore Management Review 28 (2): 47-64.

Cromie, S., 2000. "Assessing entrepreneurial inclinations: some approaches and empirical evidence". European Journal of Work and Organizational Psychology 9(1): 7-30.

Duh, M., 2003. "Family enterprises as an important factor of the economic development:the case of Slovenia". Journal of Enterprising Culture 11 (2): 111-130. Global Entrepreneurship Monitor (GEM) Report, 2006. London Business School.

Gorman, G., D. Hanlon, dan W. King, 1997. "Entrepreneurship education: the Australian perspective for the nineties". Journal of Small Business Education 9: 1-14.

Hacket, G. dan N. E. Betz, 1986. "Application of self-efficacy theory to understanding career choice behavior". Journal of Social Clinical and Phsycology 4: 279-289.

Indarti, N., 2004. "Factors affecting entrepreneurial intentions among Indonesian students". Jurnal Ekonomi dan Bisnis 19 (1): 57-70.

Indarti, N., Rostiani, R. 2008. Intensi Kewirausahaan Mahasiswa: Studi Perbandingan antara Indonesia, Jepang dan Norwegia. Online. Diakses tanggal 10 Februari 2012 http://directory.umm.ac.id

Katz, J., dan W. Gartner, 1988. "Properties of emerging organizations". Academy of Management Review 13 (3): 429-441.

Kolvereid, L., 1996. "Prediction of employment status choice intentions". Entrepreneurship Theory and Practice 21 (1): 47-57. 
Kourilsky, M. L. dan W. B. Walstad, 1998. Entrepreneurship and female youth: knowledge, attitude, gender differences, and educational practices". Journal of Business Venturing 13 (1): 77-88.

Kristiansen, S., 2001. "Promoting African pioneers in business: what makes a context conducive to small-scale entrepreneurship?". Journal of Entrepreneurship 10 (1): 43-69.

Kristiansen, S, 2002a. "Individual perception of business contexts: the case of small-scale entrepreneurs in Tanzania". Journal of Developmental Entrepreneurship 7 (3).

Kristiansen, S, 2002b. "Competition and knowledge in Javanese rural business'. Singapore Journal of Tropical Geography 23 (1): 52-70.

Kristiansen, S., B. Furuholt, dan F. Wahid, 2003. "Internet cafe entrepreneurs: pioneers in information dissemination in Indonesia". The International Journal of Entrepreneurship and Innovation 4 (4): 251-263.

Krueger, N. F. dan A. L. Carsrud, 1993. "Entrepreneurial intentions: applying the theory of planned behavior". Entrepreneurship \& Regional Development 5 (4): 315-330. Lee, J., 1997. "The motivation of women entrepreneurs in Singapore". International Journal of Entrepreneurial Behaviour and Research 3 (2): 93-110.

Marsden, K., 1992. “African entrepreneurs - pioneer of development”. Small Enterprise Development 3 (2): 15-25.

Mazzarol, T., T. Volery, N. Doss, dan V. Thein, 1999. "Factors influencing smallbusiness start-ups". International Journal of Entrepreneurial Behaviour and Research 5 (2): 48-63.

McClelland, D., 1971. The Achievement Motive in Economic Growth, in: P. Kilby (ed.) Entrepreneurship and Economic Development, New York The Free Press, 109-123. Mathews, C. H. dan S. B. Moser, 1996. "A longitudinal investigation of the impact offamily background and gender on interest in small firm ownership". Journal of Small Business Management 34 (2): 29-43.

Mead, D. C. dan C. Liedholm, 1998. "The dynamics of micro and small enterprise in developing countries". World Development 26 (1): 6174. Sabbarwal, 1994. "Determinants of entrepreneurial start-ups: a study of industrial units in India". Journal of Entrepreneurship 3 (1).

Scapinello, K. F., 1989. "Enhancing differences in the achievement attributions of high and low motivation groups". Journal of Social Psychology 129 (3): 357-363. Schiller, B.R., dan P. E. Crewson, 1997. 
"Entrepreneurial origins: a longitudinal inquiry".Economic Inquiry 35 (3): 523-531.

Scott, M. dan D. Twomey, 1988. "The long-term supply of entrepreneurs: students 'career aspirations in relation to entrepreneurship". Journal of Small BusinessManagement 26 (4): 5-13.

Sengupta, S. K. dan S. K. Debnath, 1994. "Need for achievement and entrepreneurial success: a study of entrepreneurs in two rural industries in West Bengal". The Journal of Entrepreneurship 3 (2): 191-204.

Sinha, T. N., 1996. "Human factors in entrepreneurship effectiveness". Journal of Entrepreneurship 5 (1): 23-29. 